\title{
An empirical analysis of the relation between infrastructure and road accidents
}

\author{
Lucian Lobonț ${ }^{1, *}$, and Lucian Ioan Tarnu ${ }^{1}$ \\ ${ }^{1}$ Lucian Blaga University of Sibiu, Engineering Faculty, Industrial Engineering and Management \\ Department, 550025, 4 Emil Cioran, Sibiu, România
}

\begin{abstract}
The concern for road safety in Europe is growing bigger. European Union by its means promote the aim of reducing the number of victims of traffic accidents by half in the period 2011-2020. In order to achieve this objective a lot of actions should be developed. One of our concern is the development of the infrastructure, mainly building motorways. Our research aims to study the relation between infrastructure - motorway versus highway and road accidents. Our findings show that is a great relationship between uses of motorways and reducing the number of accidents.
\end{abstract}

\section{Introduction}

The road transportation of freight and passengers counts for the most of the deaths by mean of transportation. Road traffic accidents are one of the leading causes of violent death in the European Union and at a global level. The actions promoted by the European Commission aims to reduce the number of victims of traffic accidents in the EU by half over the period 2011-2020.[1] From the many initiatives started to support the objective of reducing number of victims one of them is focusing on the safety of the infrastructure.

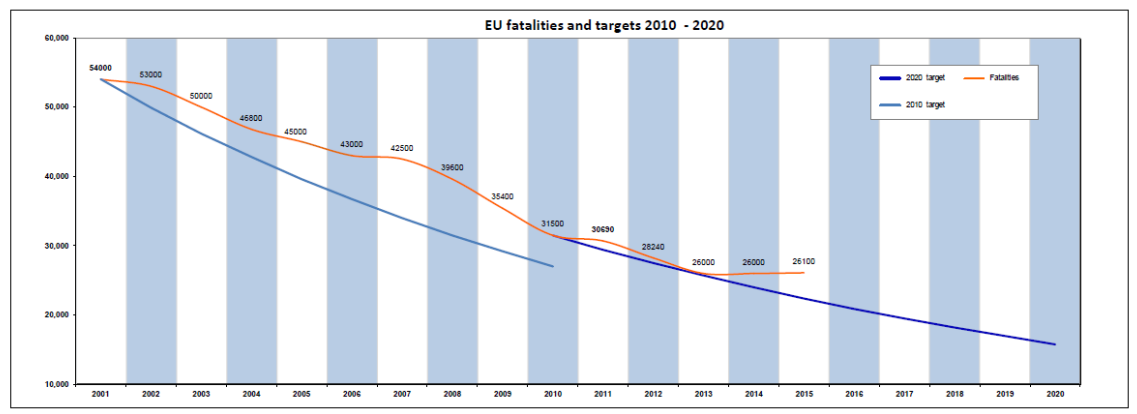

Fig. 1. Road safety evolution in EU - november 2016

\footnotetext{
* Corresponding author: lucian.lobont@ulbsibiu.ro
} 
As is shown in the figure 1[2], even the fatalities are decreasing in an accentuated way the proposed target is still far from being achieved. Analyzing the situation of people killed in road accidents in Romania we can say that it is a positive evolution during the last years. (fig. 2) [2]. In reality when the numbers are compared with the other EU countries it can be seen that Romania is far behind other countries, for example second place after Bulgaria in 2015 with $95 \mathrm{killed} / \mathrm{million}$ inhabitants. The countries from the opposite part of the graph have only $30 \mathrm{killed} / \mathrm{million}$ inhabitants. (fig. 3) [2]

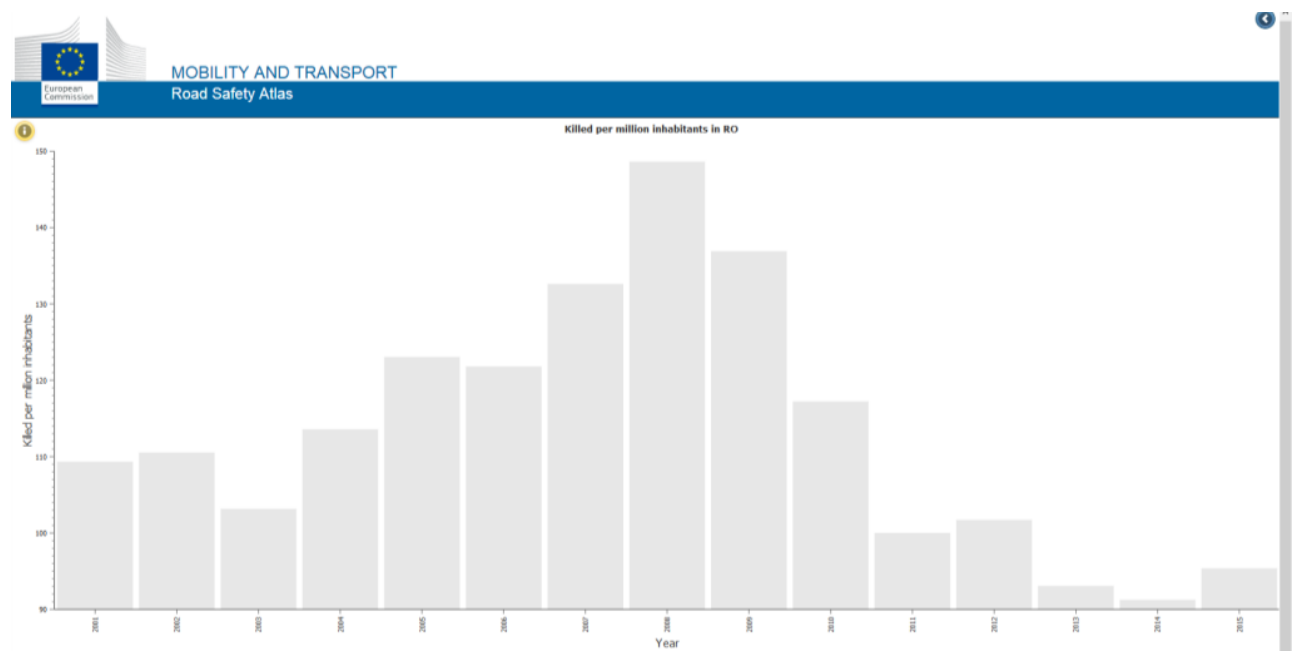

Fig. 2. Evolution of persons killed in road accidents in Romania

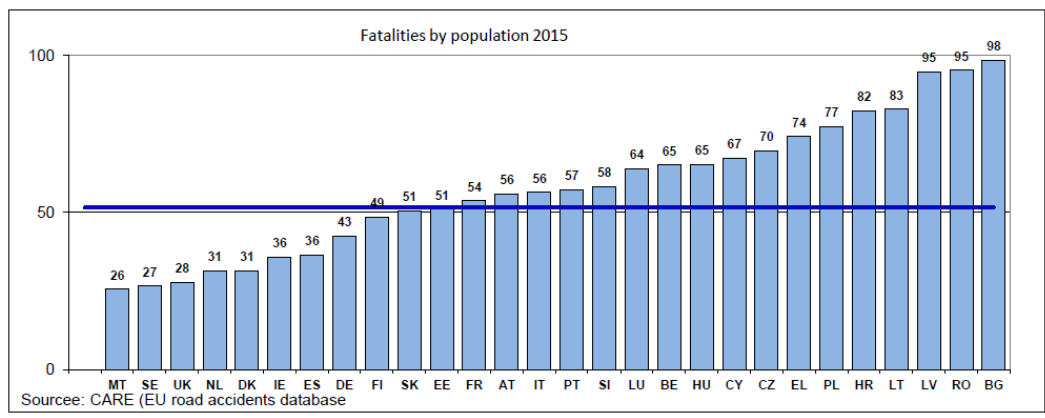

Source : CARE (EU road accidents database) or national publications

Fig. 3. Fatalities by population in EU countries

The previous researches regarding road traffic accidents is focused on different contributing factors that are connected with fatalities such as: uses of seatbelt [3], drinking, using of drugs [4,5], police inforcement [6]. Other researches [7] shows also that the risks of transportation depend on the characteristics of the road network such as road type, weather conditions, drivers' skills, and population concentration along the chosen routes.

Our research aims to study the relation between infrastructure - motorway versus highway and road accidents. 


\section{Methodology}

The analysis was conducted on a highly important road which connects the city of Sibiu in the center or Romania with the other cities situated on European corridor E81 and E68/DN1. European road E68/DN1 comprises the following: (Hungary) - Nădlac - Arad Deva - Sebeș - Miercurea Sibiului - Sibiu - Brașov respectively E81 (Ucrain) - Halmeu Livada - Satu Mare - Zalău - Cluj - Turda - Sebeș - Miercurea Sibiului - Sibiu - Pitești București -Constanța;

For our study we chose the roadways which connects the cities of Sibiu and village Cunţa at the territorial limit between Sibiu and Alba county. The road traffic between the two analyzed points can be done using a national road DN1 (highway) with $38,5 \mathrm{~km}$ length, represented with grey color in figure 4 or using the A1 motorway with 46,7 km length, represented with blue color in figure 4. According to Romanian legislation the speed limit is $100 \mathrm{~km} / \mathrm{h}$ on highway, $130 \mathrm{~km} / \mathrm{h}$ on motorway and $50 \mathrm{~km} / \mathrm{h}$ in localities.

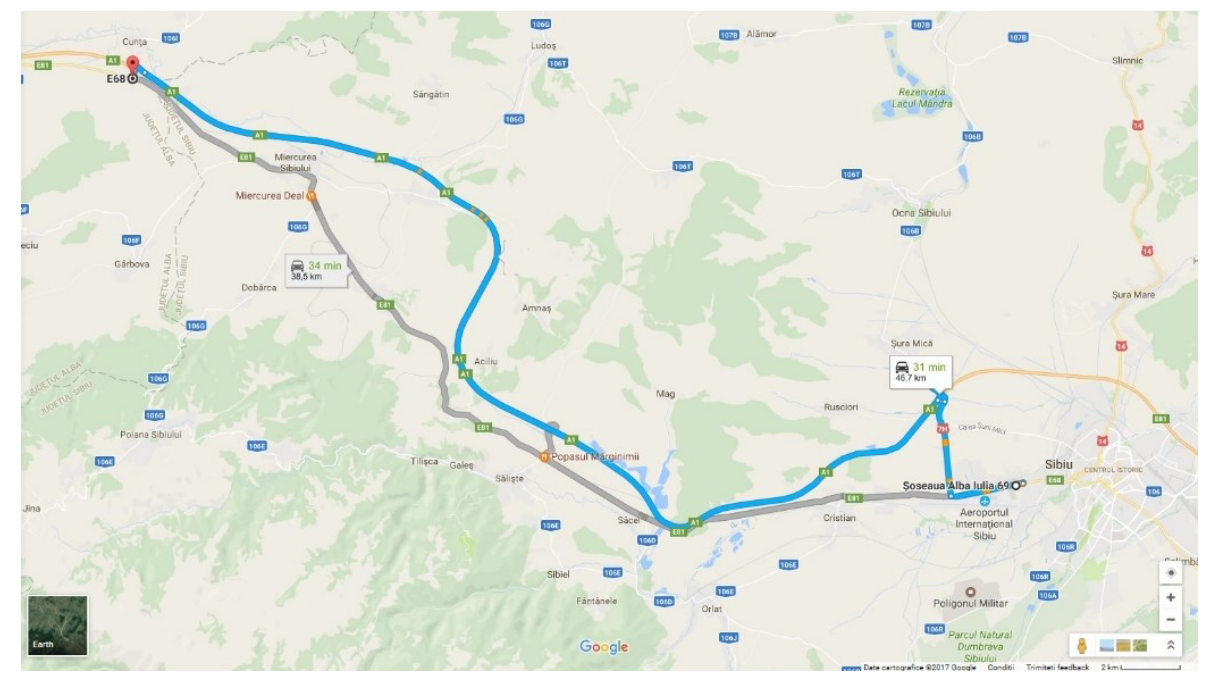

Fig. 4. Roadways chosen for the study. (image retrieved from Google Maps).

The analysis was conducted on two distinct periods:

a) 14.11.2014 - 07.09.2015 - within this time interval the motorway A1 was opened and the traffic was divided between motorway A1 and highway DN1. We estimate that most of the transit traffic was directed on A1, the highway DN1 being used for domestic traffic.

b) 07.09.2015 - 09.10.2016 - within this time interval, because of some malfunctions the motorway A1 has a closed section of $22 \mathrm{~km}(47,10 \%$ from analyzed route). In this period all the transit traffic was diverted to the highway DN1. In the figure 5 is presented with dashed line the sector of the motorway which was closed. 


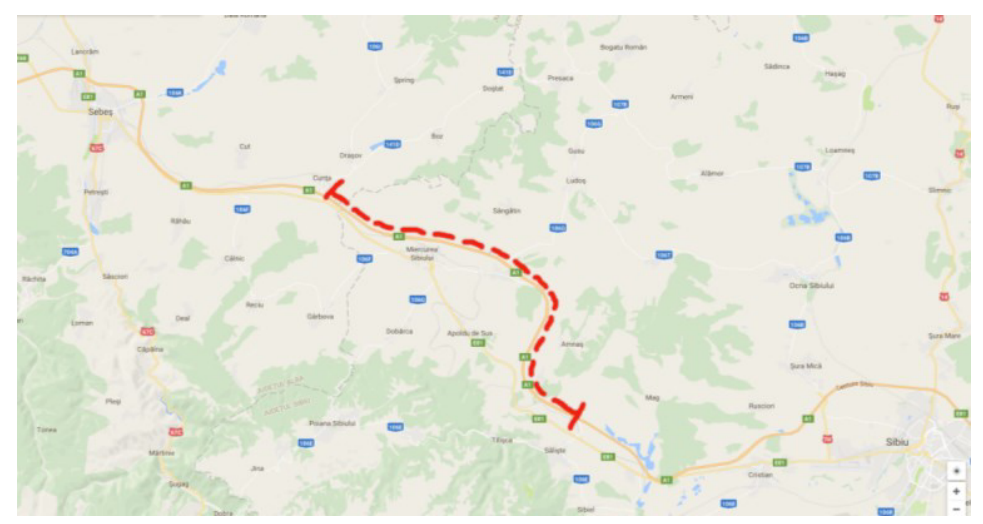

Fig. 5. Closed section of the motorway - dashed line (image retrieved from Google Maps).

The data regarding traffic accidents for the time intervals and selected roadways were exported from a national database regarding road accident. The data were analyzed in terms of quantity. The following data was extracted: number of total accidents, number of serious accidents, number of persons killed, number of persons heavily injured, number of persons injured. We extract also information regarding the main causes of accidents in the intervals analyzed and we presented the causes developing a Pareto graph which will emphasize the main causes.

\section{Results}

Retrieving the data for the two chosen intervals we obtained the following results: Period 1: 14.11.2014-07.09.2015

In the analyzed period, on DN1 Sibiu - Cunța, were 7 accidents as can be seen in Table 1.

Table 1. Number of accidents on DN1

\begin{tabular}{|c|c|c|c|c|c|}
\hline & $\begin{array}{c}\text { Total } \\
\text { accidents } \\
(\mathrm{TA})\end{array}$ & $\begin{array}{c}\text { Serious } \\
\text { accidents } \\
\text { (SA) }\end{array}$ & $\begin{array}{c}\text { Number of } \\
\text { persons killed } \\
\text { (PK) }\end{array}$ & $\begin{array}{c}\text { Heavily } \\
\text { injured (HI) }\end{array}$ & $\begin{array}{c}\text { Injured } \\
\text { (I) }\end{array}$ \\
\hline Sibiu-Sălişte & 4 & 2 & 0 & 2 & 2 \\
\hline Sălişte-Cunța & 3 & 2 & 0 & 4 & 4 \\
\hline Total & $\mathbf{7}$ & $\mathbf{4}$ & $\mathbf{0}$ & $\mathbf{6}$ & $\mathbf{6}$ \\
\hline
\end{tabular}

The main accident causes (Table 2, Table 3):

Table 2. Main accident causes Sibiu - Săliște

\begin{tabular}{|c|c|c|c|c|c|}
\hline Causes: & $\begin{array}{c}\text { Total } \\
\text { accidents } \\
(\mathrm{TA})\end{array}$ & $\begin{array}{c}\text { Serious } \\
\text { accidents } \\
(\mathrm{SA})\end{array}$ & $\begin{array}{c}\text { Number of } \\
\text { persons } \\
\text { killed (PK) }\end{array}$ & $\begin{array}{c}\text { Heavily } \\
\text { injured } \\
(\mathrm{HI})\end{array}$ & $\begin{array}{c}\text { Injured } \\
(\mathrm{I})\end{array}$ \\
\hline Bicyclists & 1 & 1 & 0 & 1 & 0 \\
\hline $\begin{array}{c}\text { Careless lane } \\
\text { change }\end{array}$ & 1 & 1 & 0 & 1 & 0 \\
\hline $\begin{array}{c}\text { Pedestrians on the } \\
\text { road }\end{array}$ & 1 & 0 & 0 & 0 & 1 \\
\hline Pedestrian crossing & 1 & 0 & 0 & 0 & 1 \\
\hline Total & $\mathbf{4}$ & $\mathbf{2}$ & $\mathbf{0}$ & $\mathbf{2}$ & $\mathbf{2}$ \\
\hline
\end{tabular}


Table 3. Main accident causes Sălişte - Cunța

\begin{tabular}{|c|c|c|c|c|c|}
\hline Causes: & $\begin{array}{c}\text { Total } \\
\text { accidents } \\
\text { (TA) }\end{array}$ & $\begin{array}{c}\text { Serious } \\
\text { accidents } \\
\text { (SA) }\end{array}$ & $\begin{array}{c}\text { Number of } \\
\text { persons } \\
\text { killed (PK) }\end{array}$ & $\begin{array}{c}\text { Heavily } \\
\text { injured } \\
\text { (HI) }\end{array}$ & $\begin{array}{c}\text { Injured } \\
\text { (I) }\end{array}$ \\
\hline $\begin{array}{c}\text { Inadequate speed at } \\
\text { road conditions }\end{array}$ & 3 & 2 & 0 & 4 & 4 \\
\hline Total & $\mathbf{3}$ & $\mathbf{2}$ & $\mathbf{0}$ & $\mathbf{4}$ & $\mathbf{4}$ \\
\hline
\end{tabular}

In the analyzed period, on A1 sector Sibiu - Cunța, were 14 accidents as can be seen in Table 4.

Table 4. Number of accidents on A1

\begin{tabular}{|c|c|c|c|c|c|}
\hline & $\begin{array}{c}\text { Total } \\
\text { accidents } \\
\text { (TA) }\end{array}$ & $\begin{array}{c}\text { Serious } \\
\text { accidents } \\
\text { (SA) }\end{array}$ & $\begin{array}{c}\text { Number of } \\
\text { persons } \\
\text { killed (PK) }\end{array}$ & $\begin{array}{c}\text { Heavily } \\
\text { injured (HI) }\end{array}$ & Injured (I) \\
\hline $\begin{array}{c}\text { A1 Sibiu }- \\
\text { Deva (km } \\
238-292)\end{array}$ & 14 & 8 & 1 & 10 & 11 \\
\hline
\end{tabular}

The main accident causes on A1 - km 238-292 (Table 5)

Table 5. Main accident causes A1

\begin{tabular}{|c|c|c|c|c|}
\hline Causes: & $\begin{array}{c}\text { Total } \\
\text { accidents } \\
\text { (TA) }\end{array}$ & $\begin{array}{c}\text { Number } \\
\text { of persons } \\
\text { killed } \\
\text { (PK) }\end{array}$ & $\begin{array}{c}\text { Heavily } \\
\text { injured (HI) }\end{array}$ & Injured (I) \\
\hline Distance between vehicle & 4 & 1 & 5 & 4 \\
\hline $\begin{array}{c}\text { Inadequate priority for other } \\
\text { vehicles }\end{array}$ & 3 & 0 & 1 & 4 \\
\hline Other causes that distract attention & 2 & 0 & 1 & 1 \\
\hline Inadequate direction change & 2 & 0 & 1 & 1 \\
\hline $\begin{array}{c}\text { Inadequate speed at road } \\
\text { conditions }\end{array}$ & 1 & 0 & 1 & 0 \\
\hline Over speeding & 1 & 0 & 1 & 0 \\
\hline Careless lane change & 1 & 0 & 0 & 1 \\
\hline Total & $\mathbf{1 4}$ & $\mathbf{1}$ & $\mathbf{1 0}$ & $\mathbf{1 1}$ \\
\hline
\end{tabular}

Total number of accidents in the analyzed period on DN1 highway cumulated with A1 motorway is presented in Table 6 .

Table 6. Total number of accidents (DN1+A1)

\begin{tabular}{|c|c|c|c|c|c|}
\hline & $\begin{array}{c}\text { Total } \\
\text { accidents } \\
\text { (TA) }\end{array}$ & $\begin{array}{c}\text { Serious } \\
\text { accidents } \\
\text { (SA) }\end{array}$ & $\begin{array}{c}\text { Number of } \\
\text { persons } \\
\text { killed (PK) }\end{array}$ & $\begin{array}{c}\text { Heavily } \\
\text { injured (HI) }\end{array}$ & Injured (I) \\
\hline $\begin{array}{c}\text { Total number } \\
\text { accidents }\end{array}$ & 21 & 12 & 1 & 16 & 17 \\
\hline
\end{tabular}

The Pareto graph of the causes of accidents is presented in figure 6. 


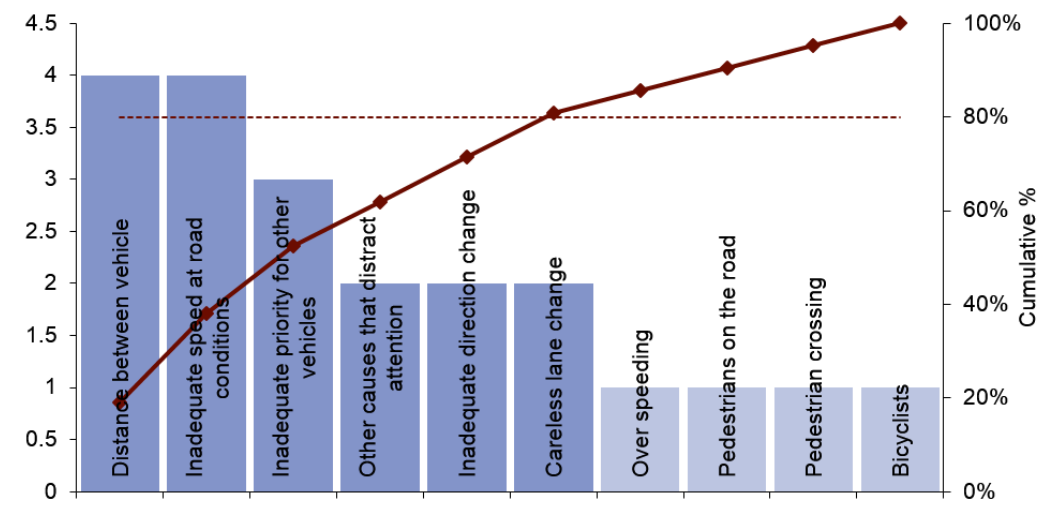

Fig. 6. Causes of accidents - period 1: 14.11.2014-07.09.2015

\section{Period 2: 07.09.2015 - 09.10.2016}

In the analyzed period, on DN1 sector Sibiu - Cunța, were 44 accidents as can be seen in Table 7.

Table 7. Number of accidents on DN1

\begin{tabular}{|c|c|c|c|c|c|}
\hline & $\begin{array}{c}\text { Total } \\
\text { accidents } \\
\text { (TA) }\end{array}$ & $\begin{array}{c}\text { Serious } \\
\text { accidents } \\
\text { (SA) }\end{array}$ & $\begin{array}{c}\text { Number of } \\
\text { persons } \\
\text { killed (PK) }\end{array}$ & $\begin{array}{c}\text { Heavily } \\
\text { injured (HI) }\end{array}$ & Injured (I) \\
\hline Sibiu-Săliște & 17 & 5 & 0 & 5 & 20 \\
\hline Săliște-Cunța & 27 & 13 & 10 & 21 & 33 \\
\hline Total & $\mathbf{4 4}$ & $\mathbf{1 8}$ & $\mathbf{1 7}$ & $\mathbf{2 6}$ & $\mathbf{5 3}$ \\
\hline
\end{tabular}

Main causes of accidents are presented in Table 8 and Table 9.

Table 8. Main accident causes Sibiu - Săliște

\begin{tabular}{|l|c|c|c|c|c|}
\hline \multicolumn{1}{|c|}{ Causes } & $\begin{array}{c}\text { Total } \\
\text { accidents } \\
\text { (TA) }\end{array}$ & $\begin{array}{c}\text { Serious } \\
\text { accidents } \\
\text { (SA) }\end{array}$ & $\begin{array}{c}\text { Number } \\
\text { of persons } \\
\text { killed } \\
\text { (PK) }\end{array}$ & $\begin{array}{c}\text { Heavily } \\
\text { injured } \\
\text { (HI) }\end{array}$ & $\begin{array}{c}\text { Injured } \\
\text { (I) }\end{array}$ \\
\hline $\begin{array}{l}\text { Inadequate priority for } \\
\text { other vehicles }\end{array}$ & 4 & 1 & 0 & 1 & 6 \\
\hline Distance between vehicle & 3 & 0 & 0 & 0 & 4 \\
\hline Careless lane change & 2 & 0 & 0 & 0 & 3 \\
\hline $\begin{array}{l}\text { Drivers of carts and } \\
\text { animals }\end{array}$ & 2 & 2 & 0 & 2 & 2 \\
\hline $\begin{array}{l}\text { Inadequate direction } \\
\text { change }\end{array}$ & 2 & 0 & 0 & 0 & 2 \\
\hline $\begin{array}{l}\text { Inadequate speed at } \\
\text { road conditions }\end{array}$ & 1 & 1 & 0 & 1 & 0 \\
\hline Pedestrian crossing & 1 & 1 & 0 & 1 & 0 \\
\hline $\begin{array}{l}\text { Other causes that } \\
\text { distract attention }\end{array}$ & 1 & 0 & 0 & 0 & 2 \\
\hline Drive without licence & 1 & 0 & 0 & 0 & 1 \\
\hline Total & $\mathbf{1 7}$ & $\mathbf{5}$ & $\mathbf{0}$ & $\mathbf{5}$ & $\mathbf{2 0}$ \\
\hline
\end{tabular}


Table 9. Main accident causes Săliște - Cunța

\begin{tabular}{|l|c|c|c|c|c|}
\hline \multicolumn{1}{|c|}{ Causes } & $\begin{array}{c}\text { Total } \\
\text { accidents } \\
\text { (TA) }\end{array}$ & $\begin{array}{c}\text { Serious } \\
\text { accidents } \\
\text { (SA) }\end{array}$ & $\begin{array}{c}\text { Number } \\
\text { of persons } \\
\text { killed } \\
\text { (PK) }\end{array}$ & $\begin{array}{c}\text { Heavily } \\
\text { injured } \\
\text { (HI) }\end{array}$ & $\begin{array}{c}\text { Injured } \\
\text { (I) }\end{array}$ \\
\hline $\begin{array}{l}\text { Inadequate speed at road } \\
\text { conditions }\end{array}$ & 19 & 9 & 8 & 18 & 23 \\
\hline $\begin{array}{l}\text { Inadequate priority for } \\
\text { other vehicles }\end{array}$ & 2 & 1 & 0 & 1 & 6 \\
\hline Distance between vehicle & 2 & 1 & 0 & 1 & 1 \\
\hline $\begin{array}{l}\text { Other causes that distract } \\
\text { attention }\end{array}$ & 1 & 0 & 0 & 0 & 2 \\
\hline Sleeping driver & 1 & 1 & 2 & 0 & 0 \\
\hline Inadequate overtaking & 1 & 0 & 0 & 0 & 1 \\
\hline $\begin{array}{l}\text { No priority for } \\
\text { pedestrians }\end{array}$ & 1 & 1 & 0 & 1 & 0 \\
\hline Total & $\mathbf{2 7}$ & $\mathbf{1 3}$ & $\mathbf{1 0}$ & $\mathbf{2 1}$ & $\mathbf{3 3}$ \\
\hline
\end{tabular}

The Pareto graph of the causes of accidents is presented in figure 7.

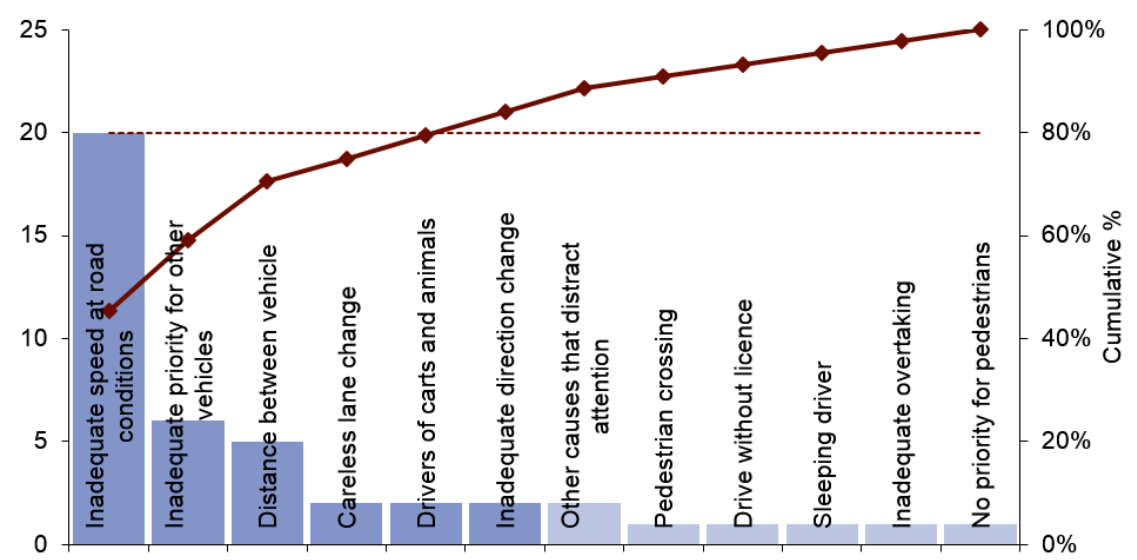

Fig. 7. Causes of accidents - period 2: 07.09.2015-09.10.2016

\section{Discussion}

The compared results from the two studied periods are presented in figure 8 .

Even if there is a difference of 101 days between the studied periods, analyzing the results, substantial increases can be observed in all the areas, increases that cannot be attributed to the difference in the number of days.

Thus, in terms of total number of accidents the values are doubled. The number of serious accidents has grown from 12 to 18 . 


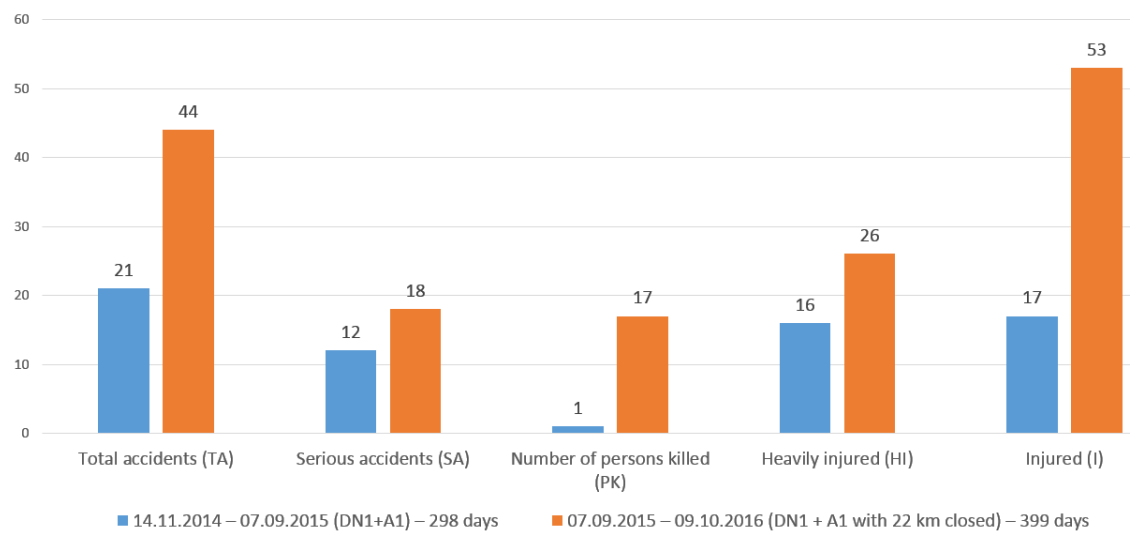

Fig. 8. Comparison of the accidents number in the two analysed periods

The consequences are visible through a terrifying increase in the number of deceased persons 17 persons within the $22 \mathrm{~km}$ of motorway were closed. There are also increases in the number of persons heavily injured and slightly injured.

Our findings, which show that the developing of the road infrastructure, especially building motorways, can help in a large decreasing of road accidents is supported also by other researchers such D. Albalate, and G. Bel, [8]

The main accident causes show different situations for the transit using national highway DN1. When the motorway was fully open there was a small number of interactions between cars and other traffic participants. After the motorway was closed the total number of interactions has grown resulting in the very big number of accidents. In order to sustain these and to emphasize the relationship between infrastructure and road accidents we can conclude analyzing the Pareto graphs that the inadequate speed, distance between vehicles and inadequate priority are the major causes of accidents but with the right infrastructure the fatal effects can be reduced.

\section{Conclusions}

While reports on road accidents recorded numerous causes for these accidents such as: inadequate speed at road conditions, inadequate priority for other vehicles, inadequate distance between vehicles, over speeding, pedestrians etc., a lot of these causes can be eliminated by developing the appropriate infrastructure, specifically building motorways. Consequently, the creation of appropriate conditions for making road transport by motorway construction impact not only by having a quick and easy transport of goods and people but also an increase in road safety and hence the saving of human lives.

It is important that the actions for reducing road accidents to be oriented not only to the obvious causes but to the fundamental ones.

\section{References}

1. Towards a European road safety area: policy orientations on road safety 2011-2020, (European Commission, Communication from the commission to the European Parliament, the council, the European economic and social committee and the committee of the regions, 2010)

2. European Commission, web site, retrieved from http://ec.europa.eu/transport/road_safety/specialist/statistics_en, (2017)

3. P.D. Loeb, Transp. Res. E Logist. Transp. Rev. 37, 297-310 (2001)

4. D. Albalate, J. Pol. Anal. Manag., 27 (1), 20-39,(2008) 
5. A. Delaney, K. Diamantopoulou, M. Cameron, Strategic Principles of Drink-Driving Enforcement. Report No. 249, (Monash University Accident Research Center, Melbourne, 2006)

6. E. O. Ryeng, Accid Anal Prev., 45, 446-454 (2012)

7. V. Torretta, E. C. Rada, M. Schiavon, P. Viotti, Safety Sci. 92, 1-9 (2017)

8. D. Albalate, G. Bel, SERIEs, 3, 457 - 473 (2012) 